
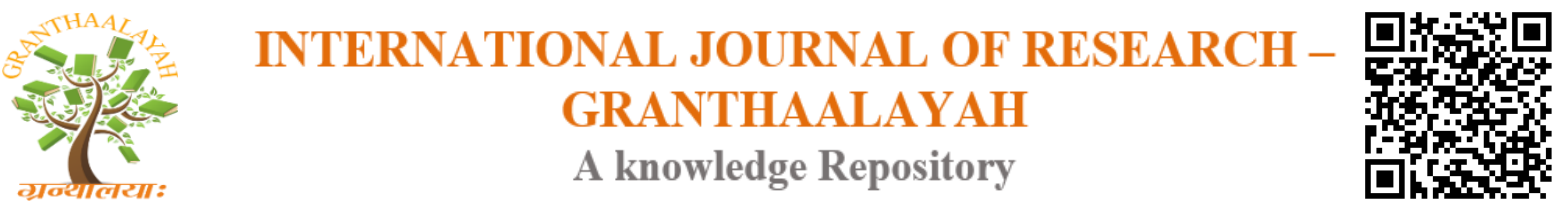

Social

\title{
EFFICACY OF IMPLEMENTATION OF PANCHAYAT JAGRATA SAMITI: A CASE STUDY OF KOZHIKODE DISTRICT, KERALA
} (INDIA)

\author{
Subair. $\mathrm{K}^{* 1}$ \\ ${ }^{* 1}$ School of Social Sciences, Central University of Gujarat, Sector 30, Gandhinagar, Gujarat- \\ 382030, India
}

\begin{abstract}
The State and Central Governments have time to time enacted legal provisions and there are lot of enforcement mechanisms to protect and prevent women and girls from the violence, but when it comes to implementation it may not work properly due to various reasons. Panchayat Jagrata Samiti (PJS) is one of the mechanisms to protect the rights of women which are considered as the prototype of Kerala Women's Commission. It has been built for attaining gender equality, equity and justice. PJS is for working dynamically by replying to complaints related to violation of women's rights along with engaging moves to safeguard the security and safety of women. It is needed for addressing the strategic needs of women for their empowerment to be practicalised in the social life situations. PJS has social responsibility to mainstreaming and upbringing gender equality in the process of decentralisation which leads to enrichment of women's status in society. This particular study tries to understand the efficacy of implantation of PJS in Kozhikode district (Kerala) and the engagements of various stakeholders. This study tries to analyse the role of PJS for protecting the rights of women and giving justice to them. This study is qualitative in methodology. The primary data is collected through semi-structured interviews, content analysis of policy documents and media reports.
\end{abstract}

Keywords: Panchayat Jagrata Samiti; Gender Equality; Justice; Kozhikode; Kerala.

Cite This Article: Subair. K. (2017). "EFFICACY OF IMPLEMENTATION OF PANCHAYAT JAGRATA SAMITI: A CASE STUDY OF KOZHIKODE DISTRICT, KERALA (INDIA)." International Journal of Research - Granthaalayah, 5(12), 112-120. https://doi.org/10.29121/granthaalayah.v5.i12.2017.479.

\section{Introduction}

Jagrata Samiti is a committee that formed at local self-government in Kerala (municipalities and panchayats). The word 'Jagrata Samiti' denotes that "Vigilance Committee". It functions from ward level to its higher level like panchayats, municipalities and district, and it holds a judicial power. It has responsibilities and rights to take cases, conduct enquiries and take proper decisions on women issues. Jagrata Samiti is one of the strong judicial bodies to protect the 
rights of women, and poor can use this without paying money. This was formed in 1997 by an order of Kerala government and was reconstituted as per the order of 2004 (Mohan 2007). It is considered as micro level Women's Commission. PJS was formed with different kinds of mechanisms to reinforce local governance and upbringing gender equality and dignity of women in the immediate process (Ibid).

In 1997, an order was issued by the government of Kerala regarding setting up district level jagrata samiti to address the violence against women and to ensure protection of women's human rights, and constituted PJS in all panchayats. PJS is a vigilant group of citizens and plays a vital role to prevent crimes against women. PJS was constituted with an idea that to help in reducing the distance between women especially from villages and various facilities offered by women commission. District panchayat samiti should be supervised by the district collector and PJS should be headed by panchayat president (Kerala Women's Commission, 2008). Two-third of committee members should be women. There should be a police officer, a lady doctor, a lady advocate, women representative of the panchayat and chairperson of Kudumbasree. ${ }^{1}$ There should be one representative from different groups such as scheduled caste, scheduled tribes, trade union and agricultural workers, youth organisation (Ibid). These are nominated by district samiti according to the recommendations of the panchayat (Ibid). Unfortunately, no scholarly works are available on jagrata samithi of Kerala in the context of efficacy of its implementation and engagements of public on it.

\section{Efficacy of the Implementation of Panchayat Jagrata Samiti-An Analysis}

The proposition of this study is to analyse the efficacy of the implementation of PJS of Kozhikode district, Kerala. It is to be assessed based on the increased understanding of people, about the governmental provisions. It is in such a socio-political state of affairs this research is conducted. As a first step, I had gone for a pilot study in January, 2011 to understand working patterns of PJS at Omassery Panchayat. As per this PJS was constituted but unfortunately it was not functioning. It was an astonishing incident to me that such a provision was not functioning there, even though there were cases to be attended based on the provisions of PJS in Omassery panchayat as it being the case all over the state. The data was collected from 12 grama panchayats of Kozhikode district for this study which were Puthuppady, Mukkam, Karassery, Kodiyathur, Kodanchery (Thiruvambady Legislative Assembly), Balussery, Panangad, Unnikulam (Balussery Legislative Assembly), Koduvally, Omassery (Kuduvally Legislative Assembly), Chathamangalam (Kunnamangalam Legislative Assembly) and Arikulam (Perambra Legislative Assembly). Mukkam panchayat was one of the panchayats where the pilot study was conducted to check the efficacy of the project by Women's Commission and it was carried out successfully then. Apart from this, most of these panchayats are situated in hilly areas and minority communities dominated areas, and number of crimes against women is reported. It is significant that the presence of people belongs to scheduled caste in all these grama panchayats and scheduled tribes in Omassery, Kodanchery, Balussery, Panangad and Arikkulam grama

\footnotetext{
${ }^{1}$ The rough meaning of the word 'Kudumbasree' is prosperity of family. Kudumbasree is a women based participatory poverty eradication programme by government of Kerala and National Bank for Agriculture and Rural Development (NABARD). It is established in 1998, which functions under the control of the local selfgovernment department. Nowadays it is one of the largest women empowered projects of the country and it covers half of the total households of Kerala (See John 2009).
} 
panchayats, and most of them have been staying in different colonies of the panchayats and they are the most vulnerable and marginalised people of these panchayats. Most of these panchayats have rural character in nature except Mukkam. Chathamangalam and Balussery (semi-urban in nature). Data was collected in 2012 and the situation of these panchayats might have been changed. An Analysis of 'efficacy of implementation of PJS' is attempted in the following, and it has divided into 11 parts.

\subsection{Consistency in Conducting Meetings of Jagrata Samiti}

Out of twelve panchayats researched only six panchayats (Kodanchery, Panangad, Chathamangalam, Unnikulam, Kodiyathur and Arikulam) had reconstituted PJS after 2010 election and only four were functioning actively which were Kodanchery, Panangad, Chathamangalam and Arikkulam panchayats. Out of twelve panchayats only four panchayats (Koduvally, Balussery, Panangad and Arikkulam) have constituted ward level Samiti in all the wards after 2010 election to LSGIs, and it is noted that panchayats, Koduvally and Balussery do not have PJS, and in these panchyats, the ward committees were constituted due to the enthusiasm of elected members for addressing women's issues. In Unnikulam panchayat ward level Samiti had been constituted in one ward only. They conducted meetings once in a month and set agenda based on the petitions received from the aggrieved and take necessary actions in dealing with the cases and programmes to be conducted. The meetings are conducted in PJS offices and it is the responsibility of the convenor to notice the meetings and all the members of PJS are vigilant in attending the meetings and planning the programmes. The convenor issues the printed agenda to all members one day before the meetings. For proper functioning of PJS with its set objectives regular meetings of the committee with vigilant interventions from the members, and proper official and administrative guidance from the specific areas are needed.

\subsection{Maintenance of the Minutes of the Meetings}

For proper functioning of a committee it needs maintenance of minutes of the meetings and appropriate follow up for planned programmes. It will help to increase the efficiency of the project with necessary reviews at definite intervals of time. With this idea in mind the respondents were enquired about maintenance of the minutes of the meetings. From the analysis it is understood that the minutes of the meetings are maintained in PJS (Kodanchery, Panangad, Chathamangalam and Arikkulam) only. In ward level Samiti there was more over an informal way of dealing with the situations and planning activities. It is very significant to maintain the minutes of the meetings for the active functioning of PJS for exact reviewing of the patterns and procedures and for follow up too.

\subsection{Areas of Actions-Significant Cases}

It being set objectives of PJS, to receive petitions and solve cases related to women and girls, to find problems related to woman and girls, and make remedy and to help panchayat for solving problems related to woman and girls the areas of actions covered by PJS have significant effect on the proper functioning. In this respect, PJS has responsibilities and rights to take cases, conduct enquiries and take proper decisions on that especially on women issues. This study presupposed that to meet the objectives and attain the goals of PJS, the significance given to 
areas of action and the significant cases considered by the committees have impact on the attainment of the goals of the project. The respondents explained the areas of actions and significant cases had been filed to PJS of their panchayats as follows.

In Kodanchery panchayat during last governing period (after 2010 election) five cases had already been reported. In Panangad panchayat, PJS was actively functioning by innovatively intervening in women's issues. As per the analysis during the period of recent governing body (after 2010 election) three cases have been reported all are concerned with family issues. In Chathamangalam grama panchayat one case has been reported. And most of these cases were solved with in Samities, one case from Kodanchery panchayat was sent to district Samiti for better handling with legal support.

\subsection{Activities Have Been Organised}

It comes under the responsibilities of PJS to protect the rights provided by Indian constitution and United Nation, to improve the prestige and dignity of women and gender equality in all levels such as political, economic, social, cultural etc. to give awareness to public about social evils such as dowry, rape, torturing, drugs etc. and to collect public opinion against films, pictures, advertisings etc. which show women as sex objects, and make legal procedures. Bearing this in mind authorities of panchayat were asked about the programmes which they had conducted.

Out of twelve panchayats only three panchayats (Kodanchery, Unnikulam and Arikkulam Panchayats) had conducted public programmes. It is noted that Chathamangalam and Panangad panchayats (they have PJS) have not organised any public programmes. Kodanchery panchayat conducted consciousness raising programmes about women's issues and awareness campaigning regarding institutional and governmental support for the advancement of women. ${ }^{2}$ They also conducted programmes focusing on the SC and ST inhabited colonies to give them life support so as to overcome the issues which they face due to subordination, and also gave counselling to the needed people. ${ }^{3}$

Unnikulam panchayat had constituted a voluntary committee which consists of seven groups of five members each. ${ }^{4}$ These groups were to check and hinder the non-social activities out raging women and each group had to roam round the town and check the issues of atrocities and report to PJS. ${ }^{5}$ This programme was effectively carried out and they were now having the control over the non-social activities which had been prevalent there. ${ }^{6}$ The paradox behind this voluntary group activity is that all the members of these groups are men.

In linking with Kerala Legal Society Arikulam panchayat had constituted an anti-liquor committee and a committee to curb the luxurious marriages. ${ }^{7}$ It was functioning effectively and

\footnotetext{
${ }^{2}$ President (Kodanchery panchayat), interviewed on 12/03/2012.

${ }^{3}$ Ibid.

${ }^{4}$ President (Unnikulam panchayat), interviewed on 13/03/2012.

5 Ibid.

6 Ibid.

${ }^{7}$ President (Arikulam panchayat), interviewed on 12/03/2012.
} 
people were energized towards such concepts and practices to fight against these social evils with the help of neighborhood groups. Public programmes are regularly conducted to maintain the slogans of these committees vibrant in the society. It can be concluded from the analysis that in addition to the Governmental provisions people's active engagements are very significant in attaining the goals of PJS.PJS functions as a result of willpower and enthusiasm of the people and the elected representatives and the administrating officials in a collective manner.

\subsection{Efficacy of Procedures of Panchayat Jagrata Samiti}

Efficacy of procedures of PJS can be assessed based on how far women could get justice fatly without spending money, women are capable to go to PJS without any fear and hesitation, and PJS provides the atmosphere for women to file and explain their cases with maximum confidence and full freedom. This study presumes that PJS assures the affected women with the revelation that there is a mechanism or system in every panchayats which offers legal support to women along with questioning the violation of women's human rights, has the capacity to avoid further incidents or shrink them.

Out of twelve panchayats only six panchayats had reconstituted PJS and four of them were working properly and a few cases were reported. On those cases PJS had been working very seriously and some of them were resolved, and some were forwarded to legal bodies. The analysis shows that the efficacy of procedure of PJS is very much linked with the sense of awareness and readiness of the elected members of panchayats and it is also correlated with the interaction between the political leadership and people. If the political leadership are conscious about the necessity of democratic relationships and gender equality, they are involving in social issues and exposing it in front of committees like PJS. Hence it can be concluded that the efficacy of the effective implementation of PJS is proportional to the attitude, responsibility, commitment and gender sensitivity of the elected members of those panchayats.

\subsection{Public Engagements in the Project}

In Kerala there is lot of cases regarding sexual harassment being reported every day. PJS is directly linked with people. To attain the goals and to accomplish the responsibilities of PJS the dynamic participation of people is very much essential. If public are to participate in people's organisational forms like PJS it would be highly appreciable. With this intention the makers of this project conceived such a provision that would enhance the acceptability and credibility of democratic functioning. The participation of the people in this project is related to effective publicity of PJS. The then Kodiyathur panchayat president said that they had reconstituted PJS after 2010 election and people did not file any petitions due to lack of publicity. This is due to the lack of awareness programmes by the panchayats. The analysis shows that public engagements in PJS is limited to four panchayats and in these panchayats, people were sharing their experiences about this project in gramasabha.

\subsection{Supporting Committees, Help Groups and Legal Aid Cell}

Due to other huge responsibilities of the elected members, it is very hard to accomplish the objectives of PJS. To attain the goals of PJS, supports of help groups is needed. It is essential to 
form a legal cell in every panchayat to help PJS in legal matters. It should be a group of advocates who are ready to help without expecting monitory benefits. Women are to be provided with information regarding higher levels of grievance redress like family courts. Unfortunately, supporting committees help groups and legal aid cell were not constituted in any of these panchayats. It shows that panchayat authorities are not very serious about this project and most of the time they are giving less importance to women's issues. For betterment of women's status and protection of their rights in male dominated society, it is needed strong positive bias towards women and better attitude towards gender equality. It is state's responsibility to take immediate actions to constitute the supporting committees for better functioning of PJS.

\subsection{Scarcity of Resources for Constituting Samiti}

In Omassery panchayat PJS had not been reconstituted after 2010 election. Panchayat president expounded that this was due to the scarcity of lady lawyer in the panchayat. ${ }^{8}$ She also explained that panchayat had enquired for a lady lawyer in near panchayats and did not get any one. ${ }^{9}$ Like this other panchayats' the then presidents explained that they had not constituted PJS due the lack of various resources. But it might be an excuse to cover up their less interest for constituting this Samiti. Several seemingly unprejudiced projects and programmes, PJS might be reinforcing existing discrimination and male dominance, in its implementation levels. Only sensitive methods of gender analysis will help to bring out gender inequality and make the development policies and projects result in equitable outcomes.

\subsection{People's Presuppositions And Bias}

This study conceptualised that people's presuppositions and bias have say on the way they reciprocate to the democratic provisions of the state. PJS is a provision which aims gender equality and gender equity in all corners of life, and protects women's rights. It also attempt to reduce atrocities against women and weaker sections of the society. With this idea in mind the respondents were asked how and whether people's presuppositions and bias affects the functioning PJS. The ex-president of Kodiyathur panchayat explained that PJS had not received any cases because the people were seeing the governing body as representation of ruling party(s). Mainly all the respondents shared the idea that the bias of people regarding the roles of women, women's secondary sexual status and attitudes. Apart from this, visions of people based on common sense and male domination add to the malfunctioning of such projects.

\subsection{Working of Monitory System}

If a system is to work properly it needs an effective positive monitoring of the projects that are planned and implemented. PJS's active engagements in women issues helps in launching the role of local governments in different social issues more linked with women. If the projects conceived are socially monitored efficiently, such provisions can be spread to immediate social life situations effectively and democratically. With this idea the respondents were asked about the social monitoring of the project. In all panchayats social monitoring of PJS had not been regularly done. Such a situation increases the hardships in effectively implementing these

\footnotetext{
${ }^{8}$ President (Omassery panchayat), interviewed on 21/02/2012.

${ }^{9}$ Ibid.
} 
provisions. This analysis shows that social monitoring of these specific projects meant for women and weaker section of the society has to be seriously taken care of because there will always be negations and negligence from the male focused society that it is not effectively working regularly.

\subsection{Inefficient Implementation}

Though there are legislative and constitution provisions aiming at gender equality, the social situation being conventional on male primacy, so the efficient implementation of the projects for gender equality have never been perfectly attainable. This issue is explicated from the analysis. It should be noted that merely having women heads will not necessarily lead to implementation of women oriented projects such as PJS. It needs concern for women's issues and their autonomy to break away from the ways and patterns of male domination. For example the analysis shows that in Puthuppady, Kodiyathur, Unnikulam, Omassery, and Koduvally panchayats women presidents were heading the governing bodies and not reconstituted PJS. But only in Kodanchery, Chathamangalam, Panangad and Arikkulam panchayats PJSs are being implemented efficiently which were headed by male presidents. Hence that it needs special consciousness raising campaigns regarding this project among all the elected representatives, officials and authorities of LSGIs, and needs positive bias towards women.

\section{Conclusion and Suggestions}

It is very important to realise that gender inequality and inequity exist in the male dominated society and that gender relations are hierarchical and traditionally maintained. It needs highest sense of being politically moral from the administrative heads and political leaderships to attain the equitable outcomes of public policies and projects. Yet it is difficult to recognise these layers of inequality through such a limited frame of research as the subordination and disadvantages due to gender difference are very deep and at times work with socially invisible designs. This study concludes on the need for addressing the strategic needs of women for their empowerment to be practicalised in social life situations.

For proper functioning of PJS with its set objectives regular meetings of the committee with vigilant interventions from the members and proper official and administrative guidance from the specific areas are very much necessary. It is also concluded that in panchayats where PJS functions effectively, almost all of them have incorporated in addressing various problems scientifically which includes counselling. In addition to the Governmental provisions active public engagements are needed in attaining the goals of PJS. Only sensitive methods of gender analysis will help to bring out gender inequality and make the development policies and projects result in equitable outcomes. It needs special consciousness raising campaigns regarding this project among all the elected representatives, officials and authorities, and social monitoring of these specific projects meant for women and weaker section of the society has to be seriously taken care of because there will always be negations and negligence from the male focused society that it is not effectively working regularly. This study identified that most of the members of Samiti are not aware of its importance and social responsibilities and due to this functions of Samiti has been crashed in some panchayats. 
It needs further studies in the future to make this project vibrant in the socio-political atmosphere of the rural areas, where resources are comparatively lower. It is not that much very easy to control crimes and atrocities against women and fight for the cause of marginalised people especially women in male dominated society.

Better social awareness, Gender sensitization to police, a vigilant community and other implementing agencies, activating PJS and apex level samities may lead to reduce the gender inequality and atrocities against women. Along with this, giving awareness to everybody about human rights especially women human rights with the active engagements of maximum people may help to reduce atrocities at extend. Understanding importance of gender equality and accepting the dignity of women are very important attempts to ensure the rights and protection of women in male dominated society. Apart from this, the apex body or the responsible authority has major obligation to constitute PJS, should never be put aside. To make an atmosphere which is favourable to women PJS has an important role in the contemporary social scenario.

\section{Government Reports}

Census (2011).Census of India 2011: Provisional Population Totals of Kerala Series 33. New Delhi: Office of Registrar General \& Census Commissioner, India. Kerala Women's Commission (2008), Jagratha Samithi- A guideline (Mal). Thiruvananthapuram: Kerala Women's Commission.

\section{Interviews}

- President (Arikulam panchayat), interviewed on 12/03/2012 at Arikulam.

- President (Balussery panchayat), interviewed on 11/03/2012 at Balussery.

- President (Chathamangalam panchayat), interviewed on 13/03/2012 at Chathamangalam

- President (Karassery panchayat), interviewed on 12/03/2012 at Karassery.

- President (Kodanchery panchayat), interviewed on 12/03/2012 at Kodanchery.

- President (Kodiyathur panchayat), interviewed on 12/03/2012 at Kodiyathur.

- President (Koduvally panchayat), interviewed on 10/03/2012 at Koduvally.

- President (Mukkam panchayat), interviewed on 11/03/2012 at Mukkam.

- President (Omassery panchayat), interviewed on 21/02/2012 at Omassery.

- President (Panangad panchayat), interviewed on 10/03/2012 at Balussery.

- President (Puthupady panchayat), interviewed on 10/03/2012 at Puthupady.

\section{Website}

http://keralapolice.org/public-information/crime-statistics/crime-against-women accessed on 05/12/2016.www.sdccapdeck.in

\section{References}

[1] John, Jacob (2009). A Study on Kudumbashree Project: A Poverty Eradication Programme in Kerala Performance, Impact and Lessons for Other States. Delhi: Planning Commission of India.

[2] Mohan, K.B Madan (2007). Gramasabha. Thiruvananthapuram: SDC- CapDecK. 
[3] Parayil, Govindan (2000). "Introduction: Is Kerala's Development Experience a 'Model'?" In Kerala: The Development Experience: Refection on Sustainability and Replicability, by Govindan Parayil, 1-15. London: Zed Books.

[4] Veron, Rene (2001). ""The "New" Kerala Model: Lessons for Sustainable Development." World Development, 29(9): 601-617.

*Corresponding author.

E-mail address: subair.kalathil@ gmail.com 